Atmos. Chem. Phys., 10, 3495-3503, 2010

www.atmos-chem-phys.net/10/3495/2010/

(C) Author(s) 2010. This work is distributed under

the Creative Commons Attribution 3.0 License.

\title{
Amine exchange into ammonium bisulfate and ammonium nitrate nuclei
}

\author{
B. R. Bzdek, D. P. Ridge, and M. V. Johnston \\ Department of Chemistry and Biochemistry, University of Delaware, Newark, DE, USA \\ Received: 10 December 2009 - Published in Atmos. Chem. Phys. Discuss.: 5 January 2010 \\ Revised: 29 March 2010 - Accepted: 7 April 2010 - Published: 16 April 2010
}

\begin{abstract}
The exchange kinetics and thermodynamics of amines for ammonia in small (1-2 nm diameter) ammonium bisulfate and ammonium nitrate clusters were investigated using electrospray ionization Fourier transform ion cyclotron resonance mass spectrometry (FT-ICR-MS). Ammonium salt clusters were reacted with amine gas at constant pressure to determine the kinetics of exchange. The reverse reactions, where aminium salt clusters reacted with ammonia gas, were also studied, and no substitution of ammonia for amine was observed. Gibbs free energy changes for these substitutions were determined to be highly exothermic, $-7 \mathrm{~kJ} / \mathrm{mol}$ or more negative in all cases. Uptake coefficients (reaction probabilities) were found to be near unity, implying that complete exchange of ammonia in small clusters by amine would be expected to occur within several seconds to minutes in the ambient atmosphere. These results suggest that if salt clusters are a component of the sub- $3 \mathrm{~nm}$ cluster pool, they are likely to be aminium salts rather than ammonium salts, even if they were initially formed as ammonium salts.
\end{abstract}

\section{Introduction}

New particle formation (NPF) has been linked to the production of cloud condensation nuclei $(\mathrm{CCN})$ (Lihavainen et al., 2003; Kerminen et al., 2005; Laaksonen et al., 2005), which can affect global climate. Predictions of the contribution of boundary layer (BL) particle formation to global and regional distributions of CCN suggest that NPF is an important contributor to the global aerosol number budget (Merikanto et al., 2009; Spracklen et al., 2006, 2008). A recent synthe-

Correspondence to: M. V. Johnston (mvj@udel.edu) sis of field studies observed that NPF increased pre-existing $\mathrm{CCN}$ number concentrations by a factor of 3.8 (Kuang et al., 2009). One reason for the apparent importance of NPF to $\mathrm{CCN}$ production is the unexpectedly high growth rates associated with these newly formed particles, which increase the probability that these particles may grow to $\sim 100 \mathrm{~nm}$ and serve as CCN. A better understanding of how new particles form and grow is imperative in order to better model aerosol climate effects.

There is evidence to suggest that amines may play an important role in the formation and/or growth of nanoparticles. Amines have been observed in the particle phase during NPF events in several locations, including Finland, Mexico, and the United States (Makela et al., 2001; Smith et al., 2010, 2008). Recent fieldwork by our group has found that the amount of nitrogen observed in nanoparticles in both urban and coastal aerosol is too large to come from ammonium salts alone, indirectly implicating amines as a substantial source of particulate nitrogen (Zordan et al., 2008). A volatility study of newly-formed particles found that nearly all nucleation mode particles had a nonvolatile core up to $280^{\circ} \mathrm{C}$, suggesting that these particles did not consist of sulfuric acid, ammonium sulfate, and water alone (Ehn et al., 2007). Another field study of aerosol from a bovine source observed that nitric acid appeared to form salts preferentially with amines rather than ammonia (Sorooshian et al., 2008). A recent study in Riverside, CA indicated that amines were strongly correlated with nitrate and sulfate during the summertime, suggesting the presence of aminium nitrate and sulfate salts (Pratt et al., 2009). Recent laboratory work has suggested that amines may enhance the growth of nanoparticles (Wang et al., 2010). Several studies also suggest that amine oxidation may lead to NPF (e.g. Malloy et al., 2009; Murphy et al., 2007).

Published by Copernicus Publications on behalf of the European Geosciences Union. 
Modeling studies suggest that amines may enhance sulfuric acid-water nucleation in the atmosphere. For instance, one group modeled the structure and formation thermodynamics of dimer clusters of sulfuric acid or bisulfate with both ammonia and amine. The authors observed that amines will usually bind more strongly than ammonia to these complexes, suggesting that amines may be more important than ammonia in enhancing both neutral and ion-induced sulfuric acid-water nucleation in the atmosphere (Kurten et al., 2008). Another recent modeling study indicated that amines may be an important contributor to organic salt formation in the atmosphere (Barsanti et al., 2009).

Amines have multiple sources, including animal husbandry (Hutchinson et al., 1982; Rabaud et al., 2003; Schade and Crutzen, 1995), biomass burning (Lobert et al., 1991), the marine environment (Facchini et al., 2008; Muller et al., 2009; Sorooshian et al., 2009; Van Neste et al., 1987), neutralization of smokestack emissions (Koornneef et al., 2008; Thitakamol et al., 2007), industrial processes (Moffet et al., 2008; Reinard et al., 2007), sewage treatment and waste incineration (Leach et al., 1999), and car exhaust (Cadle and Mulawa, 1980; Westerholm et al., 1993). Amine concentrations near animal husbandry operations, arguably the most important amine source, can be greater than $1 \mathrm{ppb}$ (Ngwabie et al., 2007; Schade and Crutzen, 1995) and have been observed in excess of $100 \mathrm{ppb}$ (Rabaud et al., 2003). However, amine concentrations are generally $2-3$ orders of magnitude below that of ammonia, so when considering the importance of amines versus ammonia in NPF, one must take into account typical ambient levels of these species. Therefore, an understanding of the kinetics and thermodynamics of substitution of amine for ammonia in ammonium salt particles would be beneficial to our understanding of the composition of newly formed particles.

The displacement of ammonia in ammonium sulfate particles by monomethylamine (MMA) has been studied previously (Murphy et al., 2007). Recent work in our group has examined the substitution of trimethylamine (TMA) for ammonia in ammonium nitrate particles with a median diameter of $300 \mathrm{~nm}$ (Lloyd et al., 2009). We observed substitution of TMA for ammonia in ammonium nitrate particles as well as substitution of ammonia for TMA in trimethylaminium nitrate particles. However, the particle size distribution was rather large $(\sim 20-500 \mathrm{~nm})$, and the effect of particle size on uptake is unknown. Additionally, neither of these two studies rigorously examined the thermodynamics or kinetics of exchange. The work presented herein systematically examines several small molecular clusters of ammonium bisulfate and ammonium nitrate and their reactions with MMA, dimethylamine (DMA), and TMA. The diameters of these clusters are on the order of $1-2 \mathrm{~nm}$, placing them in the size range of the sub- $3 \mathrm{~nm}$ neutral cluster pool continuously present in the atmosphere (Kulmala et al., 2007). Therefore, the results of this work are directly relevant to the composition of salt nuclei in the atmosphere.

\section{Experimental}

Singly-charged ammonium bisulfate clusters were introduced to a 7T Bruker Apex Qe Fourier transform ion cyclotron resonance mass spectrometer (FT-ICR-MS) operating in the positive mode by electrospray of a $0.5 \mathrm{mM}$ solution of ammonium sulfate (Aldrich) in 50/50 methanol/water. Electrospray produced an array of singly-charged ammonium bisulfate clusters of different sizes. There was no evidence in the mass spectra for formation of multiply-charged clusters. Ions of a specific cluster of interest were mass selected and accumulated in a quadrupole. Ions were then transferred to the ICR cell, where they were allowed to react to completion with a constant pressure of amine gas (DMA and TMA: Matheson Tri-Gas) that was introduced to the ICR cell via a leak valve. The reverse reaction, exposure of an aminium salt cluster to ammonia gas, was also studied. A solution of aminium sulfate $(0.5 \mathrm{mM}$ in $50 / 50 \mathrm{methanol} /$ water $)$ was made by mixing equal proportions of solutions of $2.0 \mathrm{mM}$ amine (MMA: Sigma-Aldrich; DMA and TMA: Fluka) in 50/50 methanol/water and $1.0 \mathrm{mM} \mathrm{H}_{2} \mathrm{SO}_{4}$ (Fisher) in 50/50 methanol/water. Singly-charged aminium bisulfate clusters were introduced to the instrument by electrospray of this solution and were allowed to react with ammonia gas (Matheson Tri-Gas). Solutions that contained both aminium and ammonium sulfate were made, and singlycharged ammonium bisulfate clusters partially substituted with amine were isolated and reacted with both amine and ammonia gas in order to more directly study later substitutions. The same procedure was performed for ammonium nitrate (Aldrich). The aminium nitrate solution was made by combining equal proportions of $2.0 \mathrm{mM}$ amine and $1.0 \mathrm{mM}$ nitric acid (Fisher).

A mass spectrum of ions in the ICR cell can be obtained at a specific trapping time. FT-ICR-MS provides high accuracy mass-to-charge $(\mathrm{m} / \mathrm{z})$ measurements, which allows for unique elemental formulae to be assigned to reactant and product ions. A plot of ion abundance as a function of trapping time (reaction profile) reveals the progress of the sequential substitution reactions. In some of the more exothermic reactions, the reactant molecule induces a more complicated decomposition rather than displacing a single ligand. These minor reaction-induced decomposition channels increase in importance with the difference in proton affinity between the incoming and departing ligands. The induced decompositions are not enhanced by adding unreactive argon collision gas. With the exception of one case (ammonium nitrate with TMA), reaction-induced decomposition was too small to affect the quantitative kinetic analysis of the predominant simple displacements. The data were fit to the kinetic models using the simplex method of non-linear fitting embodied in the Solver function of the Microsoft Excel program. 
Obtaining second-order rate constants required knowledge of the absolute pressure of gas in the ICR cell. However, the ICR cell pressure reading given by the ionization gauge did not correspond to the true gas pressure in the cell because of effects associated with the external magnetic field and the polarizability of the gas being measured. The absolute gas pressure was determined by the equation

$P_{\text {true }}=P_{\text {gauge }} \times K_{\text {magnet }} \times\left(\frac{\alpha_{\mathrm{N}_{2}}}{\alpha_{\text {gas }}}\right)$

where $P_{\text {true }}$ is the true ICR cell pressure, $P_{\text {gauge }}$ is the pressure reading on the ionization gauge, $K_{\text {magnet }}$ is an empirical correction factor for the effect of the magnet on the pressure reading, and $\alpha$ is the polarizability of a gas. The ionization gauge is calibrated for $\mathrm{N}_{2}$, so to obtain the pressure for another gas, the ratio of the polarizability of $\mathrm{N}_{2}$ to the polarizability of the gas used is required (Bartmess and Georgiadis, 1983).

\section{Results and discussion}

\subsection{Reaction rate constants and free energy changes}

Figure 1 presents a typical reaction profile and statistical fit for substitution of amine for ammonia in an ammonium salt cluster, in this case the reaction of DMA gas with $\left[\left(\mathrm{NH}_{4}\right)_{3}\left(\mathrm{HSO}_{4}\right)_{2}\right]^{+}$, the "3-2" ammonium bisulfate cluster. Because the pressure of DMA gas was maintained at a constant level during the experiment, pseudo-first order kinetics may be assumed. A linear dependence of the pseudo-first order rate constant on reactant gas pressure was confirmed by varying (e.g. doubling) the gas pressure. The observed change in the pseudo-first order rate constants increased linearly with pressure as expected. The data were fit to equations obtained by assuming sequential pseudo-first order reactions. For example, the three step mechanism in Eq. (2) for reactions of the 3-2 ammonium bisulfate cluster involves rate constants proportional to the fixed pressure of DMA.

$$
\begin{aligned}
{\left[\left(\mathrm{NH}_{4}\right)_{3}\left(\mathrm{HSO}_{4}\right)_{2}\right]^{+} } & \stackrel{k_{1}}{\rightarrow}\left[\left(\mathrm{NH}_{4}\right)_{2}(\mathrm{HDMA})\left(\mathrm{HSO}_{4}\right)_{2}\right]^{+} \\
& \stackrel{k_{2}}{\longrightarrow}\left[\left(\mathrm{NH}_{4}\right)(\mathrm{HDMA})_{2}\left(\mathrm{HSO}_{4}\right)_{2}\right]^{+} \\
& \stackrel{k_{3}}{\rightarrow}\left[(\mathrm{HDMA})_{3}\left(\mathrm{HSO}_{4}\right)_{2}\right]^{+}
\end{aligned}
$$

This mechanism gives rise to Eqs. (3)-(5) for the timedependent concentrations of the reactants, intermediates, and product.

$A_{1}=A_{0} e^{-k_{1} t}$

$A_{2}=\frac{k_{1} A_{0}}{k_{2}-k_{1}}\left(e^{-k_{1} t}-e^{-k_{2} t}\right)$

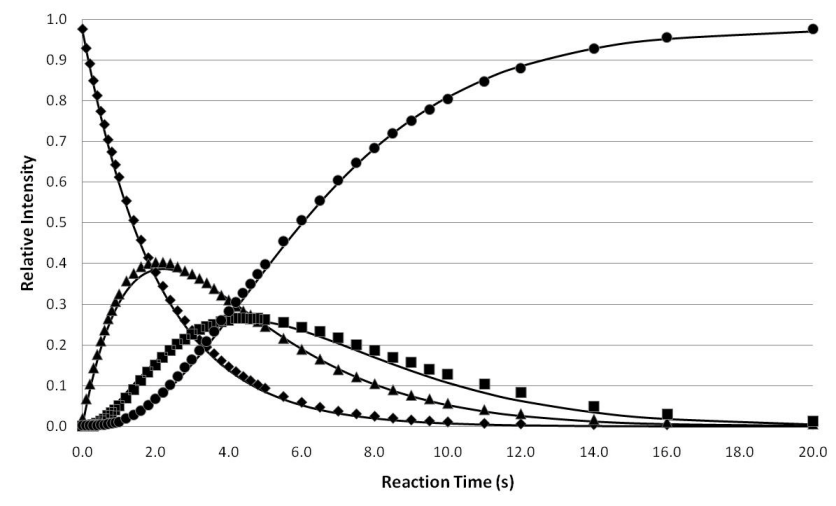

Fig. 1. Reaction profile and statistical fit for the reaction of the 3-2 ammonium bisulfate cluster with DMA. The shapes are experimental data: diamonds represent 0 DMA exchanged, triangles represent 1 DMA exchanged, squares represent 2 DMA exchanged, and circles represent 3 DMA exchanged. Solid lines are the statistical fits.

$$
\begin{aligned}
A_{3}=k_{1} k_{2} A_{0} & \left(\frac{e^{-k_{1} t}}{\left(k_{2}-k_{1}\right)\left(k_{3}-k_{1}\right)}+\frac{e^{-k_{2} t}}{\left(k_{1}-k_{2}\right)\left(k_{3}-k_{2}\right)}\right. \\
& \left.+\frac{e^{-k_{3} t}}{\left(k_{1}-k_{3}\right)\left(k_{2}-k_{3}\right)}\right)
\end{aligned}
$$

where $t$ is the reaction time (seconds); $A_{0}$ is the relative intensity of $\left[\left(\mathrm{NH}_{4}\right)_{3}\left(\mathrm{HSO}_{4}\right)_{2}\right]^{+}$at $t=0$; $A_{1}, A_{2}$, and $A_{3}$ are the relative intensities of $\left[\left(\mathrm{NH}_{4}\right)_{3}\left(\mathrm{HSO}_{4}\right)_{2}\right]^{+}, \quad\left[\left(\mathrm{NH}_{4}\right)_{2}(\mathrm{HDMA})\left(\mathrm{HSO}_{4}\right)_{2}\right]^{+}, \quad$ and $\left[\left(\mathrm{NH}_{4}\right)(\mathrm{HDMA})_{2}\left(\mathrm{HSO}_{4}\right)_{2}\right]^{+}$at time $t$, respectively; and $k_{1}$, $k_{2}$, and $k_{3}$ are the pseudo-first order rate constants for each respective substitution of amine for ammonia.

Fitting these equations simultaneously to the data gives pseudo-first order rate constants for each successive substitution. As a check of the procedure, ammonium bisulfate clusters partially substituted with DMA were produced by electrospray of a solution containing ammonia, amine, and sulfuric acid. Exposing the partially substituted clusters to DMA gas allowed each substitution step to be measured directly and successive substitutions to be determined by statistical fit of the reaction profile. The results are given in supplementary information (http://www.atmos-chem-phys.net/ 10/3495/2010/acp-10-3495-2010-supplement.pdf). In each case, the pseudo-first order rate constants obtained from the partially substituted clusters were within experimental error of the rate constants determined from the reaction profile of the original ammonium bisulfate cluster. The averages and standard deviations of all data for each substitution in the 32 cluster are given in Table 1 .

In order to calculate a second order rate constant $\left(k_{\mathrm{II}}\right)$, one must divide the pseudo-first order rate constant $\left(k_{\mathrm{I}}\right)$ by the pressure of gas in the cell $\left(P_{\text {gas }}\right)$ :

$k_{\mathrm{II}}=\frac{k_{\mathrm{I}}}{P_{\text {gas }}}$ 
Table 1. Data summary for the substitution of DMA for $\mathrm{NH}_{3}$ in the 3-2 ammonium bisulfate cluster and for the substitution of $\mathrm{NH}_{3}$ for DMA in the 3-2 dimethylaminium bisulfate cluster.

\begin{tabular}{|c|c|c|c|c|c|c|}
\hline & $\begin{array}{l}\text { Pseudo-first order } \\
\text { rate constant }\left(\mathrm{s}^{-1}\right)\end{array}$ & $\begin{array}{l}\text { Second order rate constant } \\
\left(\mathrm{cm}^{3} \text { molecule }^{-1} \mathrm{~s}^{-1}\right)\end{array}$ & $K$ & $\Delta G(\mathrm{~kJ} / \mathrm{mol})$ & $\begin{array}{l}\text { Collisional rate constant } \\
\left(\mathrm{cm}^{3} \text { molecule }^{-1} \mathrm{~s}^{-1}\right)\end{array}$ & $\begin{array}{l}\text { Uptake coefficient } \\
(\gamma)\end{array}$ \\
\hline \multicolumn{7}{|l|}{ Substitution with $\mathrm{DMA}^{\mathrm{a}}$} \\
\hline $\begin{array}{l}{\left[\left(\mathrm{NH}_{4}\right)_{3}\left(\mathrm{HSO}_{4}\right)_{2}\right]^{+} \rightarrow\left[\left(\mathrm{NH}_{4}\right)_{2}(\mathrm{HDMA})\left(\mathrm{HSO}_{4}\right)_{2}\right]^{+}} \\
{\left[\left(\mathrm{NH}_{4}\right)_{2}(\mathrm{HDMA})\left(\mathrm{HSO}_{4}\right)_{2}\right]^{+} \rightarrow\left[\left(\mathrm{NH}_{4}\right)\left(\mathrm{HDMA}_{2}\left(\mathrm{HSO}_{4}\right)_{2}\right]^{+}\right.} \\
{\left[\left(\mathrm{NH}_{4}\right)(\mathrm{HDMA})_{2}\left(\mathrm{HSO}_{4}\right)_{2}\right]^{+} \rightarrow\left[\left(\mathrm{HDMA}_{3}\left(\mathrm{HSO}_{4}\right)_{2}\right]^{+}\right.}\end{array}$ & $\begin{array}{l}0.49 \pm 0.03 \\
0.41 \pm 0.02 \\
0.43 \pm 0.03\end{array}$ & $\begin{array}{l}1.1 \pm 0.3 \times 10^{-9} \\
9.3 \pm 3.0 \times 10^{-10} \\
9.7 \pm 3.0 \times 10^{-10}\end{array}$ & $\begin{array}{l}>1500 \pm 600 \\
>620 \pm 250 \\
>26000 \pm 10000\end{array}$ & $\begin{array}{l}<-18.1 \pm 0.9 \\
<-15.9 \pm 0.8 \\
<-25.2 \pm 1.3\end{array}$ & $\begin{array}{l}1.3 \pm 0.3 \times 10^{-9} \\
1.3 \pm 0.3 \times 10^{-9} \\
1.3 \pm 0.3 \times 10^{-9}\end{array}$ & $\begin{array}{l}0.85 \pm 0.26 \\
0.72 \pm 0.22 \\
0.75 \pm 0.23\end{array}$ \\
\hline \multicolumn{7}{|l|}{ Substitution with $\mathrm{NH}_{3}^{\mathrm{b}}$} \\
\hline $\begin{array}{l}{\left[(\mathrm{HDMA})_{3}\left(\mathrm{HSO}_{4}\right)_{2}\right]^{+} \rightarrow\left[\left(\mathrm{NH}_{4}\right)(\mathrm{HDMA})_{2}\left(\mathrm{HSO}_{4}\right)_{2}\right]^{+}} \\
{\left[\left(\mathrm{NH}_{4}\right)(\mathrm{HDMA})_{2}\left(\mathrm{HSO}_{4}\right)_{2}\right]^{+} \rightarrow\left[\left(\mathrm{NH}_{4}\right)_{2}(\mathrm{HDMA})\left(\mathrm{HSO}_{4}\right)_{2}\right]^{+}} \\
{\left[\left(\mathrm{NH}_{4}\right)_{2}(\mathrm{HDMA})\left(\mathrm{HSO}_{4}\right)_{2}\right]^{+} \rightarrow\left[\left(\mathrm{NH}_{4}\right)_{3}\left(\mathrm{HSO}_{4}\right)_{2}\right]^{+}}\end{array}$ & $\begin{array}{l}<5 \pm 3 \times 10^{-4} \\
<1.8 \pm 0.8 \times 10^{-3} \\
<9 \pm 2 \times 10^{-4}\end{array}$ & $\begin{array}{l}<3.8 \pm 1.1 \times 10^{-14} \\
<1.5 \pm 0.5 \times 10^{-12} \\
<7.5 \pm 2.3 \times 10^{-13}\end{array}$ & $\begin{array}{l}<4 \pm 2 \times 10^{-5} \\
<1.6 \pm 6 \times 10^{-3} \\
<7 \pm 3 \times 10^{-4}\end{array}$ & $\begin{array}{l}>25.2 \pm 1.3 \\
>15.9 \pm 0.8 \\
>18.1 \pm 0.9\end{array}$ & $\begin{array}{l}2.0 \pm 0.4 \times 10^{-9} \\
2.0 \pm 0.4 \times 10^{-9} \\
2.0 \pm 0.4 \times 10^{-9}\end{array}$ & $\begin{array}{l}<1.9 \pm 0.6 \times 10^{-5} \\
<7.6 \pm 2.3 \times 10^{-4} \\
<3.8 \pm 1.1 \times 10^{-4}\end{array}$ \\
\hline
\end{tabular}

aPressure: $1.2 \pm 0.2 \times 10^{-8}$ torr. ${ }^{\mathrm{b}}$ Pressure: For $\left[(\mathrm{HDMA})_{3}\left(\mathrm{HSO}_{4}\right)_{2}\right]^{+}: 3.7 \pm 0.7 \times 10^{-7}$ torr; for $\left[\left(\mathrm{NH}_{4}\right)(\mathrm{HDMA})_{2}\left(\mathrm{HSO}_{4}\right)_{2}\right]^{+}$and $\left[\left(\mathrm{NH}_{4}\right)_{2}(\mathrm{HDMA})\left(\mathrm{HSO}_{4}\right)_{2}\right]^{+}: 3.4 \pm 0.7 \times 10^{-8}$ torr.

Values for the second order rate constants are also provided in Table 1. It is important to note that while the error assigned to the second order rate constant is $30 \%$, the uncertainty associated with the pseudo-first order rate constants is relatively small $(<10 \%)$. The larger error results from an uncertainty of $20 \%$ assigned to the measurement of the absolute pressure rather than imprecision in our observed reaction rates.

To probe the reverse reaction, 3-2 dimethylaminium bisulfate clusters were introduced to the ICR cell and allowed to react with gaseous $\mathrm{NH}_{3}$. However, no reaction was observed even when the gas pressure was increased as high as possible and the reaction time extended to as long a period as possible. Therefore, only upper limits of rates for this reaction could be obtained. These values were estimated by multiplying the baseline noise in the mass spectrum by a factor of three and setting that equal to the intensity of the product substituted cluster and are provided in Table 1.

Thermodynamic values, or limits on thermodynamic values, were determined from the second order rate constants. The equilibrium constant, $K$, for the reaction is given by

$K=\frac{k_{\mathrm{II}, \text { forward }}}{k_{\mathrm{II}, \text { reverse }}}$

and the Gibbs free energy change, $\Delta G$, is given by:

$\Delta G=-R T \ln K$

where $R$ is the gas constant and $T$ is temperature ( $298 \mathrm{~K}$ ).

Table 1 gives $K$ and $\Delta G$ values for substitution of DMA for $\mathrm{NH}_{3}$ in the 3-2 ammonium bisulfate cluster. Clearly substitution of amine for ammonia is thermodynamically favorable; upper limits of $\Delta G$ values are quite negative.

\subsection{Uptake coefficients (reaction probabilities)}

Determination of an uptake coefficient for a reaction requires knowledge of the collision rate. The collision rate between an ion and a (polar) molecule can be estimated in one of two ways. The capture collision model (Ridge, 2003) assumes an ion-induced dipole force between the ion (salt cluster) and molecule (reactant gas). As a result of this force, capture, a spiral inward towards zero separation, will occur at some critical impact parameter resulting in a collision between the two species. The spiraling trajectories become less important as the ion and/or molecule involved in the collision increase in size or as the relative velocity between the two increases. In these cases, the ion and molecule are more likely to impact each other before the attractive force significantly deflects their trajectories, and the collision rate is better approximated by a hard sphere model. However, for the range of conditions used in this work (small clusters with collision radii $<10 \AA$; low velocities), we expect that the capture collision model is the more appropriate approach.

The capture collision rate constant as parameterized by Su and Chesnavich (1982), $k_{\mathrm{SC}}$, is calculated from the ratio $k_{\mathrm{SC}} / k_{\mathrm{L}}$. The Langevin rate constant, $k_{\mathrm{L}}$, is given by

$k_{\mathrm{L}}=2.342 Z\left(\frac{\alpha^{\prime}}{\mu^{\prime}}\right)^{1 / 2} \times 10^{-9} \mathrm{~cm}^{3}$ molecule $^{-1} \mathrm{~s}^{-1}$

where $Z$ is the number of charges on the ion, $\alpha^{\prime}$ is the volume polarizability $\left(\AA^{3}\right)$ of the colliding molecule, and $\mu^{\prime}$ is the reduced mass of the colliding pair in atomic mass units. Note that the volume polarizability values used were as follows: $2.35 \AA^{3}$ for $\mathrm{NH}_{3}, 6.49 \AA^{3}$ for DMA, and $7.97 \AA^{3}$ for TMA (Lide, 2010). The capture collision rate constant can then be determined by

$k_{\mathrm{SC}}=\frac{k_{\mathrm{SC}}}{k_{\mathrm{L}}} \times k_{\mathrm{L}}$

where $k_{\mathrm{SC}} / k_{\mathrm{L}}$ is given by

$\frac{k_{\mathrm{SC}}}{k_{\mathrm{L}}}=0.9754+\frac{(\tau / \sqrt{2}+0.509)^{2}}{10.526} \quad 0<\tau \leq 2 \sqrt{2}$

$\frac{k_{\mathrm{SC}}}{k_{\mathrm{L}}}=0.62+0.3371 \tau \quad 2 \sqrt{2} \leq \tau$ 
Table 2. $\Delta G$ values $(\mathrm{kJ} / \mathrm{mol})$ for the substitution reactions of bisulfate clusters at $298 \mathrm{~K}$.

\begin{tabular}{lcccc}
\hline & Sub. 1 & Sub. 2 & Sub. 3 & Sub. 4 \\
\hline$\left[\left(\mathrm{NH}_{4}\right)_{2}\left(\mathrm{HSO}_{4}\right)^{+}\right.$with DMA & $<-15.1 \pm 0.8$ & $<-22.9 \pm 1.2$ & & \\
{$\left[\left(\mathrm{NH}_{4}\right)_{3}\left(\mathrm{HSO}_{4}\right)_{2}\right]^{+}$with DMA } & $<-18.1 \pm 0.9$ & $<-15.9 \pm 0.8$ & $<-25.2 \pm 1.3$ & \\
{$\left[\left(\mathrm{NH}_{4}\right)_{4}\left(\mathrm{HSO}_{4}\right)_{3}\right]^{+}$with DMA } & $<-16.5 \pm 0.8$ & $<-15.2 \pm 0.8$ & $<-12.0 \pm 0.6$ & $<-26.5 \pm 1.3$ \\
{$\left[\left(\mathrm{NH}_{4}\right)_{2}\left(\mathrm{HSO}_{4}\right)^{+}\right.$with TMA } & $<-14.1 \pm 0.7$ & $<-20.7 \pm 1.0$ & & \\
{$\left[\left(\mathrm{NH}_{4}\right)_{3}\left(\mathrm{HSO}_{4}\right)_{2}\right]^{+}$with TMA } & $<-7.0 \pm 0.4$ & $<-7.7 \pm 0.4$ & $<-15.3 \pm 0.8$ & \\
{$\left[\left(\mathrm{NH}_{4}\right)_{4}\left(\mathrm{HSO}_{4}\right)_{3}\right]^{+}$with TMA } & $<-12.8 \pm 0.6$ & & & \\
{$\left[(\mathrm{HDMA})_{2}\left(\mathrm{HSO}_{4}\right)\right]^{+}$with TMA } & $-14.0 \pm 0.7$ & $-9.5 \pm 0.5$ & & \\
{$\left[(\mathrm{HDMA})_{3}\left(\mathrm{HSO}_{4}\right)_{2}\right]^{+}$with TMA } & $-1.1 \pm 0.1$ & $-0.37 \pm 0.02$ & \multirow{2}{*}{$7.9 \pm 0.4$} & \\
\hline
\end{tabular}

and $\tau$ is a dimensionless parameter described by the equation

$$
\tau=85.11 \mu_{\mathrm{D}}^{\prime}\left(\frac{1}{\alpha^{\prime} T}\right)^{1 / 2}
$$

where $\mu_{\mathrm{D}}^{\prime}$ is the dipole moment of the molecule in Debye (D) and $T$ is the temperature in K. In general, Eq. (11) was appropriate when an amine gas was used, as the dipole moment for DMA is $1.01 \mathrm{D}$ and for TMA is $0.612 \mathrm{D}$ (Lide, 2010). Equation (12) was appropriate for reaction with ammonia gas, which has a dipole moment of 1.471 D (Lide, 2010).

Uptake coefficients $(\gamma)$ were determined by the equation

$\gamma=\frac{k_{\mathrm{II}}}{k_{\mathrm{SC}}}$

Table 1 provides collisional rate constants and uptake coefficients for both the substitution of DMA for $\mathrm{NH}_{3}$ in 3-2 ammonium bisulfate and the substitution of $\mathrm{NH}_{3}$ for DMA in 3-2 dimethylaminium bisulfate. Since the reverse reaction was not observed, only upper estimates of uptake coefficients were possible. Substitution kinetics and energetics are discussed in more detail below.

\subsection{Bisulfate clusters}

The procedures described above were performed for bisulfate clusters of several different sizes and compositions. Not only were ammonium bisulfate clusters investigated, but also the substitution of one amine for another in different aminium bisulfate clusters was studied so as to determine the favorability of one amine versus another in a bisulfate salt. $\Delta G$ values for substitution in bisulfate clusters are provided in Table 2, while uptake coefficients for these reactions are provided in Table 3.

It is evident based on $\Delta G$ values that substitution of amine for ammonia is highly favorable. Since the reverse reaction (substitution of ammonia for amine) was not observed, only upper limits for $\Delta G$ were determined. However, in the case of substitution of TMA for DMA in dimethylaminium bisulfate, both the forward and reverse reactions were observed, so actual $\Delta G$ values were determined. One general conclusion based on these thermodynamic results is that reaction is favorable when substitution occurs by a more polarizable species. Table 4 provides proton affinity and enthalpy of solvation values for ammonia and the aliphatic amines. By comparing $\Delta G$ values to proton affinity differences, it appears that proton affinity is a good guide for determining the favorability of substitution in most cases. However, since measurements were not absolute for the ammonium bisulfate clusters, exactly how good of a guide proton affinity values may be is uncertain, but initial substitution of TMA for DMA in $2-1$ dimethylaminium bisulfate gives a $\Delta G$ value $(14.0 \pm 0.7 \mathrm{~kJ} / \mathrm{mol})$ close to the difference in proton affinity between DMA and TMA $(20 \mathrm{~kJ} / \mathrm{mol})$. However, in the 32 dimethylaminium bisulfate cluster, substitution of TMA for DMA becomes unfavorable after the second substitution, which is what would be predicted based on enthalpy of solvation values. DMA solvates better than TMA; therefore, based on enthalpy of solvation values, substitution should be unfavorable. The unfavorability may also be due to steric interactions between TMA and the cluster as well as the loss of one hydrogen bond that occurs upon substitution of TMA. Therefore, while proton affinity may be a good predictor for initial substitution, enthalpy of solvation may be a better predictor for subsequent substitutions.

An examination of the uptake coefficients for bisulfate clusters agrees with this analysis. In the case of ammonium bisulfate clusters reacting with amine, uptake coefficients are close to unity, indicating that substitution occurs near the collision rate. The same is true for the reaction of monomethylaminium bisulfate with both DMA and TMA. In general, the first substitution occurred the fastest. Subsequent substitutions, while still quite fast, were slightly slower. This behavior can be explained by collisions of amine with the cluster occurring in places where substitution had already occurred, resulting in no net reaction. This trend does not appear to apply for the final substitution of the 4-3 ammonium bisulfate 
Table 3. Uptake coefficients for the substitution reactions of bisulfate clusters.

\begin{tabular}{|c|c|c|c|c|}
\hline & $\gamma_{1}$ & $\gamma_{2}$ & $\gamma_{3}$ & $\gamma_{4}$ \\
\hline$\left[\left(\mathrm{NH}_{4}\right)_{2}\left(\mathrm{HSO}_{4}\right)\right]^{+}$with DMA & $1.05 \pm 0.26$ & $0.97 \pm 0.24$ & & \\
\hline$\left[\left(\mathrm{NH}_{4}\right)_{3}\left(\mathrm{HSO}_{4}\right)_{2}\right]^{+}$with DMA & $0.85 \pm 0.22$ & $0.72 \pm 0.18$ & $0.75 \pm 0.19$ & \\
\hline$\left[\left(\mathrm{NH}_{4}\right)_{4}\left(\mathrm{HSO}_{4}\right)_{3}\right]^{+}$with DMA & $0.61 \pm 0.15$ & $0.56 \pm 0.14$ & $0.58 \pm 0.15$ & $0.83 \pm 0.21$ \\
\hline$\left[(\mathrm{HMMA})_{2}\left(\mathrm{HSO}_{4}\right)\right]^{+}$with DMA & $1.05 \pm 0.26$ & $0.70 \pm 0.18$ & & \\
\hline$\left[(\mathrm{HMMA})_{3}\left(\mathrm{HSO}_{4}\right)_{2}\right]^{+}$with DMA & $0.82 \pm 0.20$ & $0.71 \pm 0.18$ & $0.64 \pm 0.16$ & \\
\hline$\left[(\mathrm{HMMA})_{4}\left(\mathrm{HSO}_{4}\right)_{3}\right]^{+}$with DMA & $0.85 \pm 0.21$ & $0.80 \pm 0.20$ & $0.69 \pm 0.17$ & $0.66 \pm 0.16$ \\
\hline$\left[(\mathrm{HTMA})_{2}\left(\mathrm{HSO}_{4}\right)\right]^{+}$with DMA & $8.6 \pm 2.2 \times 10^{-3}$ & $1.8 \pm 0.5 \times 10^{-3}$ & & \\
\hline$\left[(\mathrm{HTMA})_{3}\left(\mathrm{HSO}_{4}\right)_{2}\right]^{+}$with DMA & $0.51 \pm 0.13$ & $0.22 \pm 0.05$ & $0.18 \pm 0.05$ & \\
\hline$\left[\left(\mathrm{NH}_{4}\right)_{2}\left(\mathrm{HSO}_{4}\right)\right]^{+}$with TMA & $0.90 \pm 0.26$ & $0.65 \pm 0.26$ & & \\
\hline$\left[\left(\mathrm{NH}_{4}\right)_{3}\left(\mathrm{HSO}_{4}\right)_{2}\right]^{+}$with TMA & $0.66 \pm 0.26$ & $0.45 \pm 0.26$ & $0.57 \pm 0.26$ & \\
\hline$\left[\left(\mathrm{NH}_{4}\right)_{4}\left(\mathrm{HSO}_{4}\right)_{3}\right]^{+}$with TMA & $0.64 \pm 0.26$ & $0.48 \pm 0.26$ & $0.39 \pm 0.26$ & $1.07 \pm 0.26$ \\
\hline$\left[(\mathrm{HMMA})_{2}\left(\mathrm{HSO}_{4}\right)\right]^{+}$with TMA & $1.07 \pm 0.27$ & $0.54 \pm 0.13$ & & \\
\hline$\left[(\mathrm{HMMA})_{3}\left(\mathrm{HSO}_{4}\right)_{2}\right]^{+}$with TMA & $0.75 \pm 0.19$ & $0.60 \pm 0.15$ & $0.39 \pm 0.10$ & \\
\hline$\left[(\mathrm{HMMA})_{4}\left(\mathrm{HSO}_{4}\right)_{3}\right]^{+}$with TMA & $0.76 \pm 0.19$ & $0.69 \pm 0.17$ & $0.55 \pm 0.14$ & $0.13 \pm 0.03$ \\
\hline$\left[(\mathrm{HDMA})_{2}\left(\mathrm{HSO}_{4}\right)\right]^{+}$with TMA & $0.62 \pm 0.15$ & $0.47 \pm 0.12$ & & \\
\hline$\left[(\mathrm{HDMA})_{3}\left(\mathrm{HSO}_{4}\right)_{2}\right]^{+}$with TMA & $0.33 \pm 0.08$ & $0.30 \pm 0.07$ & $0.025 \pm 0.006$ & \\
\hline$\left[(\mathrm{HDMA})_{4}\left(\mathrm{HSO}_{4}\right)_{3}\right]^{+}$with TMA & $0.36 \pm 0.09$ & $0.050 \pm 0.013$ & $0.014 \pm 0.004$ & $3.9 \pm 1.0 \times 10^{-3}$ \\
\hline$\left[(\mathrm{HMMA})_{2}\left(\mathrm{HSO}_{4}\right)\right]^{+}$with $\mathrm{NH}_{3}$ & $<1.1 \pm 0.3 \times 10^{-3}$ & $<1.7 \pm 0.5 \times 10^{-3}$ & & \\
\hline$\left[(\mathrm{HMMA})_{3}\left(\mathrm{HSO}_{4}\right)_{2}\right]^{+}$with $\mathrm{NH}_{3}$ & $3 \pm 1 \times 10^{-4}$ & $<3.1 \pm 0.9 \times 10^{-4}$ & $<3 \pm 1 \times 10^{-4}$ & \\
\hline$\left[(\mathrm{HMMA})_{4}\left(\mathrm{HSO}_{4}\right)_{3}\right]^{+}$with $\mathrm{NH}_{3}$ & $<1.0 \pm 0.3 \times 10^{-4}$ & $<8 \pm 3 \times 10^{-5}$ & $<4 \pm 1 \times 10^{-4}$ & $<4 \pm 1 \times 10^{-4}$ \\
\hline$\left[(\mathrm{HDMA})_{2}\left(\mathrm{HSO}_{4}\right)\right]^{+}$with $\mathrm{NH}_{3}$ & $<6 \pm 2 \times 10^{-5}$ & $<1.6 \pm 0.5 \times 10^{-3}$ & & \\
\hline$\left[(\mathrm{HDMA})_{3}\left(\mathrm{HSO}_{4}\right)_{2}\right]^{+}$with $\mathrm{NH}_{3}$ & $<1.9 \pm 0.6 \times 10^{-5}$ & $<8 \pm 2 \times 10^{-4}$ & $<4 \pm 1 \times 10^{-4}$ & \\
\hline$\left[(\mathrm{HDMA})_{4}\left(\mathrm{HSO}_{4}\right)_{3}\right]^{+}$with $\mathrm{NH}_{3}$ & $<1.2 \pm 0.4 \times 10^{-5}$ & $<3.0 \pm 0.9 \times 10^{-3}$ & $<8 \pm 2 \times 10^{-4}$ & $<5 \pm 2 \times 10^{-4}$ \\
\hline$\left[(\mathrm{HTMA})_{2}\left(\mathrm{HSO}_{4}\right)\right]^{+}$with $\mathrm{NH}_{3}$ & $<9 \pm 3 \times 10^{-5}$ & $<1.7 \pm 0.5 \times 10^{-3}$ & & \\
\hline$\left[(\mathrm{HTMA})_{3}\left(\mathrm{HSO}_{4}\right)_{2}\right]^{+}$with $\mathrm{NH}_{3}$ & $<6 \pm 2 \times 10^{-4}$ & $<1.1 \pm 0.3 \times 10^{-2}$ & $<2.1 \pm 0.6 \times 10^{-2}$ & \\
\hline$\left[(\mathrm{HTMA})_{4}\left(\mathrm{HSO}_{4}\right)_{3}\right]^{+}$with $\mathrm{NH}_{3}$ & & & & $<1.9 \pm 0.6 \times 10^{-3}$ \\
\hline
\end{tabular}

Table 4. Proton affinity and enthalpy of solvation values for $\mathrm{NH}_{3}$ and the aliphatic amines (Lide, 2010).

\begin{tabular}{ccc}
\hline & $\begin{array}{c}\text { Proton Affinity } \\
(\mathrm{kJ} / \mathrm{mol})\end{array}$ & $\begin{array}{c}\text { Enthalpy of } \\
\text { Solvation }(\mathrm{kJ} / \mathrm{mol})\end{array}$ \\
\hline $\mathrm{NH}_{3}$ & 853.6 & -35.4 \\
MMA & 899.0 & -45.3 \\
DMA & 929.5 & -53.1 \\
TMA & 948.9 & -52.7 \\
\hline
\end{tabular}

cluster with amine, as this substitution occurs more quickly than previous substitutions. We hypothesize that this observation may arise because enough internal energy has been built up in the cluster to allow for a rearrangement to occur, making substitution more facile. However, we must note that the uncertainties associated with these uptake coefficients are relatively large, so one must be cautious in making any def-
Table 5. $\Delta G$ values $(\mathrm{kJ} / \mathrm{mol})$ for the substitution reactions of nitrate clusters at $298 \mathrm{~K}$.

\begin{tabular}{llll}
\hline & Sub. 1 & Sub. 2 & Sub. 3 \\
\hline$\left[\left(\mathrm{NH}_{4}\right)_{3}\left(\mathrm{NO}_{3}\right)_{2}\right]^{+}$ & & & $<-24.2 \pm 1.2$ \\
with DMA & & & \\
{$\left[(\mathrm{HDMA})_{2}\left(\mathrm{NO}_{3}\right)\right]^{+}$} & $-13.7 \pm 0.7$ & $-9.9 \pm 0.5$ & \\
with TMA & & & \\
\hline
\end{tabular}

inite conclusions. In the case of trimethylaminium bisulfate reacting with DMA, substitution in the $2-1$ cluster is unfavorable, which would be predicted based on proton affinity values. For the 3-2 cluster, though, substitution is observed, which would be predicted based on enthalpy of solvation values. Overall, later substitutions in a cluster occurred more quickly when reacting with DMA than TMA, likely due to steric hindrance with TMA. 
Table 6. Uptake coefficients for the substitution reactions of nitrate clusters.

\begin{tabular}{lcccc}
\hline & $\gamma_{1}$ & $\gamma_{2}$ & $\gamma_{3}$ & $\gamma_{4}$ \\
\hline$\left[\left(\mathrm{NH}_{4}\right)_{3}\left(\mathrm{NO}_{3}\right)_{2}\right]^{+}$with DMA & $0.53 \pm 0.21$ & $0.50 \pm 0.17$ & $0.68 \pm 0.12$ & \\
{$\left[(\mathrm{HMMA})_{2}\left(\mathrm{NO}_{3}\right)\right]^{+}$with DMA } & $0.86 \pm 0.25$ & $0.55 \pm 0.18$ & & \\
{$\left[(\mathrm{HMMA})_{3}\left(\mathrm{NO}_{3}\right)_{2}\right]^{+}$with DMA } & $0.77 \pm 0.21$ & $0.66 \pm 0.17$ & $0.47 \pm 0.12$ & \\
{$\left[(\mathrm{HTMA})_{2}\left(\mathrm{NO}_{3}\right)\right]^{+}$with DMA } & $6.4 \pm 1.9 \times 10^{-3}$ & $2.0 \pm 0.6 \times 10^{-3}$ & & \\
{$\left[\left(\mathrm{NH}_{4}\right)_{3}\left(\mathrm{NO}_{3}\right)_{2}\right]^{+}$with TMA } & $0.40 \pm 0.12$ & & & \\
{$\left[(\mathrm{HMMA})_{2}\left(\mathrm{NO}_{3}\right)\right]^{+}$with TMA } & $0.84 \pm 0.25$ & $0.59 \pm 0.18$ & & \\
{$\left[(\mathrm{HMMA})_{3}\left(\mathrm{NO}_{3}\right)_{2}\right]^{+}$with TMA } & $0.71 \pm 0.21$ & $0.55 \pm 0.17$ & $0.39 \pm 0.12$ & \\
{$\left[(\mathrm{HMMA})_{4}\left(\mathrm{NO}_{3}\right)_{3}\right]^{+}$with TMA } & $0.76 \pm 0.23$ & $0.57 \pm 0.17$ & $0.43 \pm 0.13$ & $\mathrm{xx}$ \\
{$\left[(\mathrm{HDMA})_{2}\left(\mathrm{NO}_{3}\right)\right]^{+}$with TMA } & $0.60 \pm 0.18$ & $0.40 \pm 0.12$ & & \\
{$\left[(\mathrm{HDMA})_{3}\left(\mathrm{NO}_{3}\right)_{2}\right]^{+}$with TMA } & $0.22 \pm 0.07$ & $0.16 \pm 0.05$ & $0.016 \pm 0.006$ & \\
{$\left[(\mathrm{HDMA})_{4}\left(\mathrm{NO}_{3}\right)_{3}\right]^{+}$with TMA } & $0.13 \pm 0.04$ & $0.025 \pm 0.008$ & $5.6 \pm 1.7 \times 10^{-3}$ & $\mathrm{xx}$ \\
{$\left[(\mathrm{HMMA})_{3}\left(\mathrm{NO}_{3}\right)_{2}\right]^{+}$with NH} & $<2.2 \pm 0.7 \times 10^{-4}$ & & $<0.029 \pm 0.009$ & \\
{$\left[(\mathrm{HDMA})_{2}\left(\mathrm{NO}_{3}\right)\right]^{+}$with $\mathrm{NH}_{3}$} & $<1.0 \pm 0.3 \times 10^{-4}$ & & & \\
{$\left[(\mathrm{HDMA})_{3}\left(\mathrm{NO}_{3}\right)_{2}\right]^{+}$with $\mathrm{NH}_{3}$} & $<2.5 \pm 0.8 \times 10^{-5}$ & & & \\
{$\left[(\mathrm{HTMA})_{2}\left(\mathrm{NO}_{3}\right)\right]^{+}$with $\mathrm{NH}_{3}$} & $<9 \pm 3 \times 10^{-5}$ & & & \\
\hline
\end{tabular}

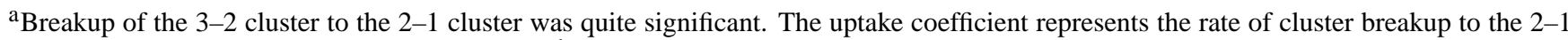
cluster compared to the collisional rate constant. ${ }^{b}$ For these $4-3$ clusters, the final substitution of TMA appeared to induce cluster breakup.

\subsection{Nitrate clusters}

Substitution kinetics and thermodynamics were also investigated for nitrate clusters. Thermodynamic results are provided in Table 5; kinetic results are provided in Table 6. In general, nitrate clusters were more difficult to study than bisulfate clusters. Ammonium nitrate volatilizes at low temperatures, so obtaining a stable ion signal for one cluster was a challenging problem. Clusters also appeared to be less strongly bound, so energetic substitutions in some cases introduced moderate to significant cluster dissociation. Significant cluster dissociation was evident for the 3-2 ammonium nitrate cluster reacting with TMA; however this cluster appeared to dissociate to the analogous 2-1 cluster at a rate close to collision rate. Additionally, both the 4 3 monomethylaminium and dimethylaminium nitrate clusters appeared to dissociate upon their final substitution with TMA. Rate constants (and, therefore, uptake coefficients) were not ascertained for the final substitution because these species were not observed. However, it appears that substitution did occur for this step, as significant cluster dissociation was observed at this point in the reaction, which is the opposite of what is normally observed upon the final substitution (that is, virtually no cluster dissociation is observed). Overall, results from nitrate clusters were in agreement with results from bisulfate clusters. Of particular note is that $\Delta G$ values for the substitution of TMA for DMA in 2-1 dimethylaminium nitrate are in agreement within experimental error to the $\Delta G$ values for the analogous substitution in dimethylaminium bisulfate.

Therefore, it appears that amines displace ammonia at or near collision rate for small bisulfate and nitrate clusters. Initial substitution is generally favorable when a species with higher proton affinity displaces one with lower proton affinity.

\subsection{Reaction of ions vs. neutrals}

It should be noted that in order to study these small clusters using mass spectrometry, they must exist as charged species. Nonetheless, we expect that these results would also apply to neutral clusters, which appear to be dominant in the atmosphere (Kulmala et al., 2007). Within one specific cluster size, there generally were no large (i.e. order of magnitude) differences in the observed rate constants from one substitution to the next, which would be indicative of charge playing an important role in the reaction. Additionally, the differences in substitution rate constants for clusters of different sizes (i.e. 2-1 ammonium bisulfate vs. 3-2 ammonium bisulfate vs. 4-3 ammonium bisulfate) were minimal. If charge were playing an important role in these reactions, significant differences from one size cluster to the next would be apparent; however, since this was not observed, it is likely that charge played a minimal role in these substitution reactions. 


\section{Atmospheric implications}

The results of this work have important atmospheric implications. These clusters have diameters that are about 1-2 nanometers, which fall into the size range of the stable pool of clusters that has been implicated in NPF (Kulmala et al., 2007). For a 1-nm diameter cluster exposed to an ambient amine level of $1 \mathrm{ppb}$, i.e. near an amine source, the collision rate would be on the order of $30 \mathrm{~s}^{-1}$. Based on the near unity uptake coefficients measured in this work, complete conversion of ammonium to aminium in the cluster would be expected to occur in less than a second. If the ambient amine concentration were in the low ppt level, i.e. further away from an amine source, complete conversion still would be expected within several seconds to minutes. These results suggest that if salt clusters are a component of the sub-3 nm cluster pool, they are likely to be aminium salts rather than ammonium salts, even if they were initially formed as ammonium salts. Ammonium salt clusters would be expected to persist only when (1) the formation rate of new clusters exceeds the cluster collision rate with amine or (2) the growth rate of a cluster by collision with ammonia exceeds the cluster collision rate with amine. The concept of rapid, complete conversion of ammonium salts to aminium salts applies only to relatively small clusters. As the cluster size increases, the corresponding surface to volume ratio decreases and the time required to achieve complete conversion becomes excessively long.

Acknowledgements. The authors gratefully acknowledge the assistance of Jeffrey M. Spraggins with FT-ICR experimental details. BRB acknowledges a graduate fellowship from the University of Delaware Center for Critical Zone Research. This research was supported by NSF Grant No. CHE-0808972.

Edited by: M. Ammann

\section{References}

Barsanti, K. C., McMurry, P. H., and Smith, J. N.: The potential contribution of organic salts to new particle growth, Atmos. Chem. Phys., 9, 2949-2957, 2009, http://www.atmos-chem-phys.net/9/2949/2009/.

Bartmess, J. E. and Georgiadis, R. M.: Empirical methods for determination of ionization gauge relative sensitivities for different gases, Vacuum, 33, 149-153, 1983.

Cadle, S. H. and Mulawa, P. A.: Low molecular weight aliphatic amines in exhaust from catalyst-equipped cars, Environ. Sci. Technol., 14, 718-723, 1980.

Ehn, M., Petäjä, T., Birmili, W., Junninen, H., Aalto, P., and Kulmala, M.: Non-volatile residuals of newly formed atmospheric particles in the boreal forest, Atmos. Chem. Phys., 7, 677-684, 2007 ,

http://www.atmos-chem-phys.net/7/677/2007/.

Facchini, M. C., Decesari, S., Rinaldi, M., Carbone, C., Finessi, E., Mircea, M., Fuzzi, S., Moretti, F., Tagliavini, E., Ceburnis, D., and O'Dowd, C. D.: Important source of marine secondary organic aerosol from biogenic amines, Environ. Sci. Technol., 42, 9116-9121, 2008.

Hutchinson, G. L., Mosier, A. R., and Andre, C. E.: Ammonia and amine emissions from a large cattle feedlot, J. Environ. Quality, 11, 288-293, 1982.

Kerminen, V. M., Lihavainen, H., Komppula, M., Viisanen, Y., and Kulmala, M.: Direct observational evidence linking atmospheric aerosol formation and cloud droplet activation, Geophys. Res. Lett., 32, L14803, doi:10.1029/2005g1023130, 2005.

Koornneef, J., van Keulen, T., Faaij, A., and Turkenburg, W.: Life cycle assessment of a pulverized coal power plant with postcombustion capture, transport and storage of $\mathrm{CO}_{2}$, International Journal of Greenhouse Gas Control, 2, 448-467, 2008.

Kuang, C., McMurry, P. H., and McCormick, A. V.: Determination of cloud condensation nuclei production from measured new particle formation events, Geophys. Res. Lett., 36, L09822, doi: 10.1029/2009g1037584, 2009.

Kulmala, M., Riipinen, I., Sipila, M., Manninen, H. E., Petaja, T., Junninen, H., Dal Maso, M., Mordas, G., Mirme, A., Vana, M., Hirsikko, A., Laakso, L., Harrison, R. M., Hanson, I., Leung, C., Lehtinen, K. E. J., and Kerminen, V. M.: Toward direct measurement of atmospheric nucleation, Science, 318, 89-92, 2007.

Kurtén, T., Loukonen, V., Vehkamki, H., and Kulmala, M.: Amines are likely to enhance neutral and ion-induced sulfuric acid-water nucleation in the atmosphere more effectively than ammonia, Atmos. Chem. Phys., 8, 4095-4103, 2008,

http://www.atmos-chem-phys.net/8/4095/2008/.

Laaksonen, A., Hamed, A., Joutsensaari, J., Hiltunen, L., Cavalli, F., Junkermann, W., Asmi, A., Fuzzi, S., and Facchini, M. C.: Cloud condensation nucleus production from nucleation events at a highly polluted region, Geophys. Res. Lett., 32, L06812, doi:10.1029/2004g1022092, 2005.

Leach, J., Blanch, A., and Bianchi, A. C.: Volatile organic compounds in an urban airborne environment adjacent to a municipal incinerator, waste collection centre and sewage treatment plant, Atmos. Environ., 33, 4309-4325, 1999.

Lide, D. R.: CRC Handbook of Chemistry and Physics, 90th Edition (Internet Version 2010), CRC Press/Taylor Francis, Boca Raton, FL, 2010.

Lihavainen, H., Kerminen, V. M., Komppula, M., Hatakka, J., Aaltonen, V., Kulmala, M., and Viisanen, Y.: Production of "potential" cloud condensation nuclei associated with atmospheric new particle formation in northern Finland, J. Geophys. Res.-Atmos., 108, 4782, doi:10.1029/2003jd003887, 2003.

Lloyd, J. A., Heaton, K. J., and Johnston, M. V.: Reactive uptake of trimethylamine into ammonium nitrate particles, J. Phys. Chem. A., 113, 4840-4843, 2009.

Lobert, J. M., Scharffe, D. H., Hao, W., Kuhlbusch, T. A., Warneck, P., and Crutzen, P. J.: Experimental evaluation of biomass burning emissions: Nitrogen and carbon containing compounds, in: Global Biomass Burning: Atmospheric, Climatic and Biospheric Implications, edited by: Levine, J. S., MIT Press, Cambridge, MA, 1991.

Makela, J. M., Yli-Koivisto, S., Hiltunen, V., Seidl, W., Swietlicki, E., Teinila, K., Sillanpaa, M., Koponen, I. K., Paatero, J., Rosman, K., and Hameri, K.: Chemical composition of aerosol during particle formation events in boreal forest, Tellus Series BChemical and Physical Meteorology, 53, 380-393, 2001.

Malloy, Q. G. J., Li Qi, Warren, B., Cocker III, D. R., Erupe, M. 
E., and Silva, P. J.: Secondary organic aerosol formation from primary aliphatic amines with $\mathrm{NO}_{3}$ radical, Atmos. Chem. Phys., 9, 2051-2060, 2009, http://www.atmos-chem-phys.net/9/2051/2009/.

Merikanto, J., Spracklen, D. V., Mann, G. W., Pickering, S. J., and Carslaw, K. S.: Impact of nucleation on global CCN, Atmos. Chem. Phys., 9, 8601-8616, 2009,

http://www.atmos-chem-phys.net/9/8601/2009/.

Moffet, R. C., de Foy, B., Molina, L. T., Molina, M. J., and Prather, K. A.: Measurement of ambient aerosols in northern Mexico City by single particle mass spectrometry, Atmos. Chem. Phys., 8, 4499-4516, 2008,

http://www.atmos-chem-phys.net/8/4499/2008/.

Müller, C., Inuma, Y., Karstensen, J., van Pinxteren, D., Lehmann, S., Gnauk, T., and Herrmann, H.: Seasonal variation of aliphatic amines in marine sub-micrometer particles at the Cape Verde islands, Atmos. Chem. Phys., 9, 9587-9597, 2009,

http://www.atmos-chem-phys.net/9/9587/2009/.

Murphy, S. M., Sorooshian, A., Kroll, J. H., Ng, N. L., Chhabra, P., Tong, C., Surratt, J. D., Knipping, E., Flagan, R. C., and Seinfeld, J. H.: Secondary aerosol formation from atmospheric reactions of aliphatic amines, Atmos. Chem. Phys., 7, 2313-2337, 2007, http://www.atmos-chem-phys.net/7/2313/2007/.

Ngwabie, N. M., Schade, G. W., Custer, T. G., Linke, S., and Hinz, T.: Volatile organic compound emission and other trace gases from selected animal buildings, Landbauforschung Volkenrode, 57, 273-284, 2007.

Pratt, K. A., Hatch, L. E., and Prather, K. A.: Seasonal volatility dependence of ambient particle phase amines, Environ. Sci. Technol., 43, 5276-5281, 2009.

Rabaud, N. E., Ebeler, S. E., Ashbaugh, L. L., and Flocchini, R. G.: Characterization and quantification of odorous and non-odorous volatile organic compounds near a commercial dairy in California, Atmos. Environ., 37, 933-940, 2003.

Reinard, M. S., Adou, K., Martini, J. M., and Johnston, M. V.: Source characterization and identification by real-time single particle mass spectrometry, Atmos. Environ., 41, 9397-9409, 2007.

Ridge, D. P.: Ion-molecule collision theory, in: The Encyclopedia of Mass Spectrometry, edited by: Armentrout, P. B., Elsevier, San Diego, CA, 1-8, 2003.

Schade, G. W. and Crutzen, P. J.: Emission of aliphatic amines from animal husbandry and their reactions: Potential source of $\mathrm{N}_{2} \mathrm{O}$ and HCN, J. Atmos. Chem., 22, 319-346, 1995.

Smith, J. N., Dunn, M. J., VanReken, T. M., Iida, K., Stolzenburg, M. R., McMurry, P. H., and Huey, L. G.: Chemical composition of atmospheric nanoparticles formed from nucleation in Tecamac, Mexico: Evidence for an important role for organic species in nanoparticle growth, Geophys. Res. Lett., 35, L04808, doi:10.1029/2007g1032523, 2008.
Smith, J. N., Barsanti, K. C., Friedli, H. R., Ehn, M., Kulmala, M., Collins, D. R., Scheckman, J. H., Williams, B. J., and McMurry, P. H.: Observations of aminium salts in atmospheric nanoparticles and possible climatic implications, Proceedings of the National Academy of Sciences of the United States of America, 107, 6634-6639, 2010.

Sorooshian, A., Murphy, S. M., Hersey, S., Gates, H., Padro, L. T., Nenes, A., Brechtel, F. J., Jonsson, H., Flagan, R. C., and Seinfeld, J. H.: Comprehensive airborne characterization of aerosol from a major bovine source, Atmos. Chem. Phys., 8, 5489-5520, 2008, http://www.atmos-chem-phys.net/8/5489/2008/.

Sorooshian, A., Padro, L. T., Nenes, A., Feingold, G., McComiskey, A., Hersey, S. P., Gates, H., Jonsson, H. H., Miller, S. D., Stephens, G. L., Flagan, R. C., and Seinfeld, J. H.: On the link between ocean biota emissions, aerosol, and maritime clouds: Airborne, ground, and satellite measurements off the coast of California, Global Biogeochem. Cy., 23, Gb4007, doi:10.1029/2009gb003464, 2009.

Spracklen, D. V., Carslaw, K. S., Kulmala, M., Kerminen, V.-M., Mann, G. W., and Sihto, S.-L.: The contribution of boundary layer nucleation events to total particle concentrations on regional and global scales, Atmos. Chem. Phys., 6, 5631-5648, 2006, http://www.atmos-chem-phys.net/6/5631/2006/.

Spracklen, D. V., Carslaw, K. S., Kulmala, M., Kerminen, V. M., Sihto, S. L., Riipinen, I., Merikanto, J., Mann, G. W., Chipperfield, M. P., Wiedensohler, A., Birmili, W., and Lihavainen, H.: Contribution of particle formation to global cloud condensation nuclei concentrations, Geophys. Res. Lett., 35, L06808, doi:10.1029/2007g1033038, 2008.

$\mathrm{Su}$, T. and Chesnavich, W. J.: Parametrization of the ion-polar molecule collision rate constant by trajectory calculations, J. Chem. Phys., 76, 5183-5185, 1982.

Thitakamol, B., Veawab, A., and Aroonwilas, A.: Environmental impacts of absorption-based $\mathrm{CO}_{2}$ capture unit for postcombustion treatment of flue gas from coal-fired power plant, International Journal of Greenhouse Gas Control, 1, 318-342, 2007.

Van Neste, A., Duce, R. A., and Lee, C.: Methylamines in the marine atmosphere, Geophys. Res. Lett., 14, 711-714, 1987.

Wang, L., Khalizov, A. F., Zheng, J., Xu, W., Ma, Y., Lal, V., and Zhang, R.: Atmospheric nanoparticles formed from heterogeneous reactions of organics, Nature Geosci., 3, 238-242, doi:10.1038/ngeo778, 2010.

Westerholm, R., Li, H., and Almen, J.: Estimation of aliphatic amine emissions in automobile exhausts, Chemosphere, 27, 1381-1384, 1993.

Zordan, C. A., Wang, S., and Johnston, M. V.: Time-resolved chemical composition of individual nanoparticles in urban air, Environ. Sci. Technol., 42, 6631-6636, 2008. 